\title{
Disaster Awareness and Preparedness of Barrio Community in Zambales, Philippines: Creating a Baseline for Curricular Integration and Extension Program
}

\author{
Danilo V. ROGAYAN Jr.'
}

President Ramon Magsaysay State University, Zambales, PHILIPPINES
Lea F. DOLLETE2

President Ramon Magsaysay State University, Zambales, PHILIPPINES

'Corresponding author: Prof.; President Ramon Magsaysay State University, College of Education, Arts \& Sciences,

Zambales, Philippines. danrogayan [at] prmsu.edu.ph ORCID: 0000-0002-8597-7202

2 Prof; President Ramon Magsaysay State University, College of Teacher Education, Zambales, Philippines. leadollete [at] yahoo.com ORCID: 0000-0003-0765-9396

\section{Abstract}

This cross-sectional descriptive survey research determines the extent of disaster awareness and preparedness of the barrio or barangay community from the five southern municipalities of Zambales, Philippines. A total of 480 residents responded to the study. Results revealed that a majority of respondents were moderately aware about the different disasters occurring in the community. They are very aware about a typhoon whilst being moderately aware about a tsunami and storm surge. In terms of hazard level, respondents perceived a typhoon to be 'very destructive', whilst they understood a tsunami and storm surge to be 'strong'. The barrio community often practice disaster preparedness for earthquakes, strong typhoons, landslides, fire, flood and volcanic eruptions. Amongst residents of the barrios, a moderate correlation exists $(r=0.449)$ between their levels of disaster awareness and disaster preparedness. The results of this study provide a baseline information to use in decisions about the integration of disaster science and management in the curriculum at basic and higher education levels. Moreover, it also provided insights into the crafting of a community extension program to be spearheaded by the university. Such a program accentuates the need for massive dissemination of information about disasters forlocal communities so they become more aware about the causes and consequences of disasters. The proposed curriculum integration and extension program may inform practitioners and policy makers in making sound decisions regarding disaster risk reduction and mitigation strategies.

\section{Keywords}

Disaster Preparedness, Disaster Awareness, Disaster Risk Reduction, Disaster Education 
Planet Earth is presently in distress due to multifarious problems engendered by atrocious human activities that continuously damage the environment (Rogayan, 2019). Additionally, the planet is also confronted with a myriad of natural hazards that continue to variously impact different countries across the globe. The risks associated with such hazards and disasters are further exacerbated by industrial development, disruptive technologies and other anthropogenic activities.

Disaster is a repercussion from an environmental event or man-made conflict that gives rise to significant tension, injury, physical destruction, and economic disturbance. Disasters lead to detrimental impacts on people, goods, services and/or natural habitat and often exceeds the effective capacity of a community to respond (Department of Disaster Management - Virgin Islands, $2011)$. The social and economic costs of natural hazards have risen in the past years in response to population growth, and changes in the trends of land use, mobility and unforeseen industrialization, environmental denudation and global climatic change.

Globally, there is extensive literature dedicated to risk management. Such literature focuses on knowledge, attitudes and practices (KAPs) about disasters (AlQahtany, \& Abubakar, 2020; Ahayalimudin \& Osman, 2016; Pinar, 2017), disaster management and risk reduction practices (Amaratunga, Malalgoda, Haigh, Panda, \& Rahayu, 2018; Djalante, Garschagen, Thomalla, \& Shaw, 2017; Macnight Ngwese, Saito, Sato, Agyeman Boafo, \& Jasaw, 2018; Rasaki, 2019; Shahbaz, 2019; Tiwari, \& Rayamajhi, 2018), and disaster preparedness and response practices (llo, Izuagbe, Mole, \& Ekwueme, 2018; Taşkıran, \& Baykal, 2019). A number of studies also focus on the KAPs in specific disasters such as earthquakes (Baytiyeh, \& Ocal, 2016; Ersoy, \& Kocak, 2016), and floods (Dobrucali, \& Demir, 2016). Such studies served as baseline information to enhance the disaster risk management and response strategies in different communities across the globe.

The Philippines is situated in a zone that is susceptible to disasters thereby making it one of the world's most disaster-prone countries (Cinco et al., 2016; Valenzuela, Esteban, Takagi, Thao, \& Onuki, 2020). The geographical location of the Philippines makes the country uniquely susceptible to a multitude of hazards including intermittent typhoons, earthquakes, and volcanic eruptions which are globally considered to be the deadliest and costliest hazard (Doroteo, 2015). Other hazards include flooding, landslides, tsunamis and wildfires, all of which occur at a pace and have profoundly changed the country's view of hazards (Office for Disaster Risk Reduction, UN, 2019).

As reported by the World Bank (2005), natural disasters weaken poverty alleviation programs and cause diversion of government funds to pay for rehabilitation and recovery efforts; natural disasters also cause loss of life and substantial degradation of economic and social infrastructure. In response to this, the Philippines has enacted the Republic Act 10121 otherwise known as the Philippine Disaster Risk Reduction and Management Act of 2010. This legislation has laid the groundwork for a paradigm change from merely disaster preparedness to disaster risk reduction and management (DRRM). The goal is to support gender-responsive and rights-based sustainable development practice for people's welfare and security (Republic Act No. 10121, 2010). 
Given that the Philippines is vulnerable to disasters and hazards due to its geographical location and geology, the community needs to be aware about and be prepared to deal with the possibility of different disasters occurring regularly. Studies conducted in the Philippines have focused on disaster resilience (Usamah, Handmer, Mitchell, \& Ahmed, 2014), community-based disaster awareness (Valenzuela et al., 2020), indigenous knowledge and practices on disaster (Quilo et al., 2015), disaster awareness and preparedness of the academic libraries (Superio, Alayon, \& Oliveros, 2019), disaster preparedness of nurses (Labrague, Yboa, McEnroe-Petitte, Lobrino, \& Brennan, 2016), youth involvement in disaster risk reduction (Fernandez, \& Shaw, 2015), and community leaders' disaster preparedness and resiliency (Matunhay, 2018).

Zambales is one of the most disaster provinces of the Philippines. The province is located in Central Luzon on the island of Luzon. The geographical location of Zambales made the province prone to typhoons originating from the Pacific Ocean on the eastern side of the country which made it also vulnerable to flooding (Farin, Co, \& Farin, 2017). Zambales province is also the home of the Mt. Pinatubo, an andesitic-dacitic stratovolcano, which erupted in June 1991. A substantial amount of pyroclastic materials has been deposited on the western slopes of the Bataan Volcanic Complex and the Zambales Mountain Range due to the eruption (Rodolfo et al., 1996, as cited in Zuluaga et al., 2017). Pinatubo eruption was the second largest destructive volcanic eruption of the twentieth century; it was also the eruption that is globally considered to have caused major environmental consequences to a heavily populated region (Newhall \& Punongbayan, 1997, as cited in Zuluaga et al., 2017).

Previous studies about disasters in Zambales focus on disaster science and management (Abugho, Angeles \& Dacayo, 2016), flood disaster (Farin et al., 2017; Paz-Alberto et al., 2016; Paz-Alberto et al., 2019; Subia, Jocson, \& Florencondia, 2019), typhoon (De Viana, 2016), volcanic eruption (Newhall, \& Solidum, 2017; Reid, 2017), and earthquake (Causapin, 2018). The present study, however, seeks to investigate the awareness and preparedness of the community in response to different man-made and natural disasters.

\section{Purpose of the Study}

The research ascertains the disaster awareness and preparedness of the barrio communities of Southern Zambales, to provide baseline information for decisions to be made about curriculum enhancement and extension program development. The research questions considered here are the following:

- What are the common disasters experienced by the barrio community?

- How do the respondents perceive the hazard level of various disasters?

- How aware are the respondents on the nature, impact and threats of disasters?

- What is the extent of respondents' preparedness in the different disasters?

- Is there a significant relationship between disaster awareness and disaster preparedness of the respondents?

- What intervention program can be proposed to promote awareness and preparedness in disaster risk reduction among Zambales barrio residents? 


\section{Conceptual Framework}

Disaster preparedness is influenced by variations in people's perceptions, values and socio-cultural attitudes towards certain forms of hazardous events (Paton, Smith, \& Johnston, 2005). In line with the disaster risk reduction efforts of the Philippine government, it is imperative to undertake a local research about the extent to which the barrio community are conscious of and prepared for disasters in their locality (Figure 1).

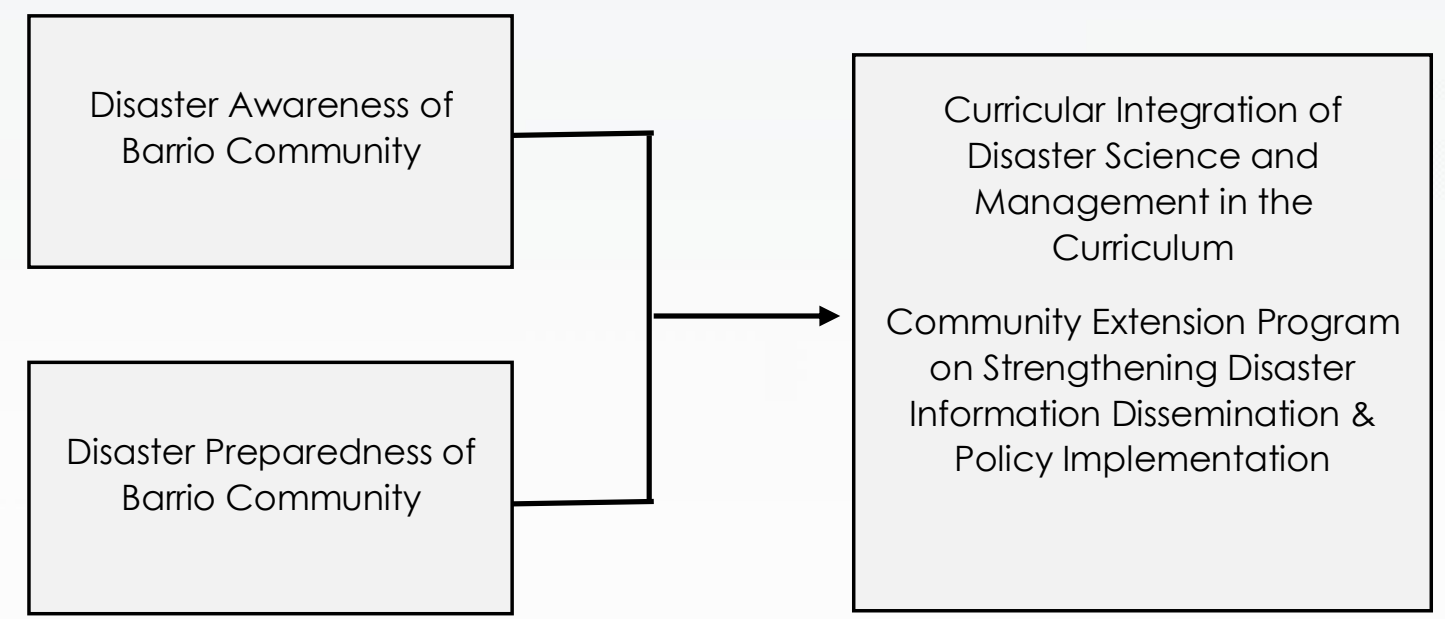

Figure 1. Conceptual framework of the Study

Findings of this study will yield baseline data which would be helpful in reviewing the curriculum offered by the university in terms of decisions about integrating significant concepts of disaster preparedness across all subjects. In the Philippines, disaster science and management concepts are taught in basic science and environmental science courses, and to integrate such concepts into other disciplines will further assist the development of disaster-ready and disasterresilient communities. Results from the current study will further strengthen information dissemination about different disasters to local communities so they become more aware about the causes and consequences of disasters through participation in a community extension program. The lowest ratings reported by the respondents in the survey about disaster awareness and disaster preparedness will form the basis for formulating decisions about curricular integration in higher education and the crafting of a community extension program. The baseline data obtained from the survey will guide the researchers in designing the disaster education program; it is also recommended that the baseline data could be used to strengthen policy development and implementation.

Strengthening the disaster awareness and disaster preparedness of barrio communities in the Zambales province of the Philippines will be primarily achieved through education. Hence, the full integration of disaster education across the curriculum is critical. Moreover, the development of extension and community programs by the universities may focus on developing the capacity of barrio communities about disaster science and management. Disaster experience promotes disaster awareness (Hoffmann, \& Muttarak, 2017). 


\section{Methodology}

\section{Research Design}

The research utilized a cross-sectional descriptive survey design with a surveyquestionnaire being the main instrument for gathering data. Cross-sectional research is a method whereby researchers examine a situation affecting a group at any point in time (Creswell, 2005). The cross-sectional survey method is the most commonly used survey design compared to surveys used in longitudinal studies. One reason for this is primarily due to the shorter amount of time required in the gathering of information (Creswell, 2005). A cross-sectional survey is also suitable for use in the current study because it is descriptive in nature and this research is a one-shot point in time survey for the purpose of simply describing the characteristics of a sample at one point in time (Mertens, 2005).

\section{Research Site}

The site of the study was in southern Zambales in Central Luzon, Philippines (Figure 2) and includes five towns: San Narciso, San Antonio, San Marcelino, Castillejos, and Subic. The sites were selected because barrio communities in these towns have experienced major disasters such as earthquake, typhoon, volcanic eruption, landslide, and others.

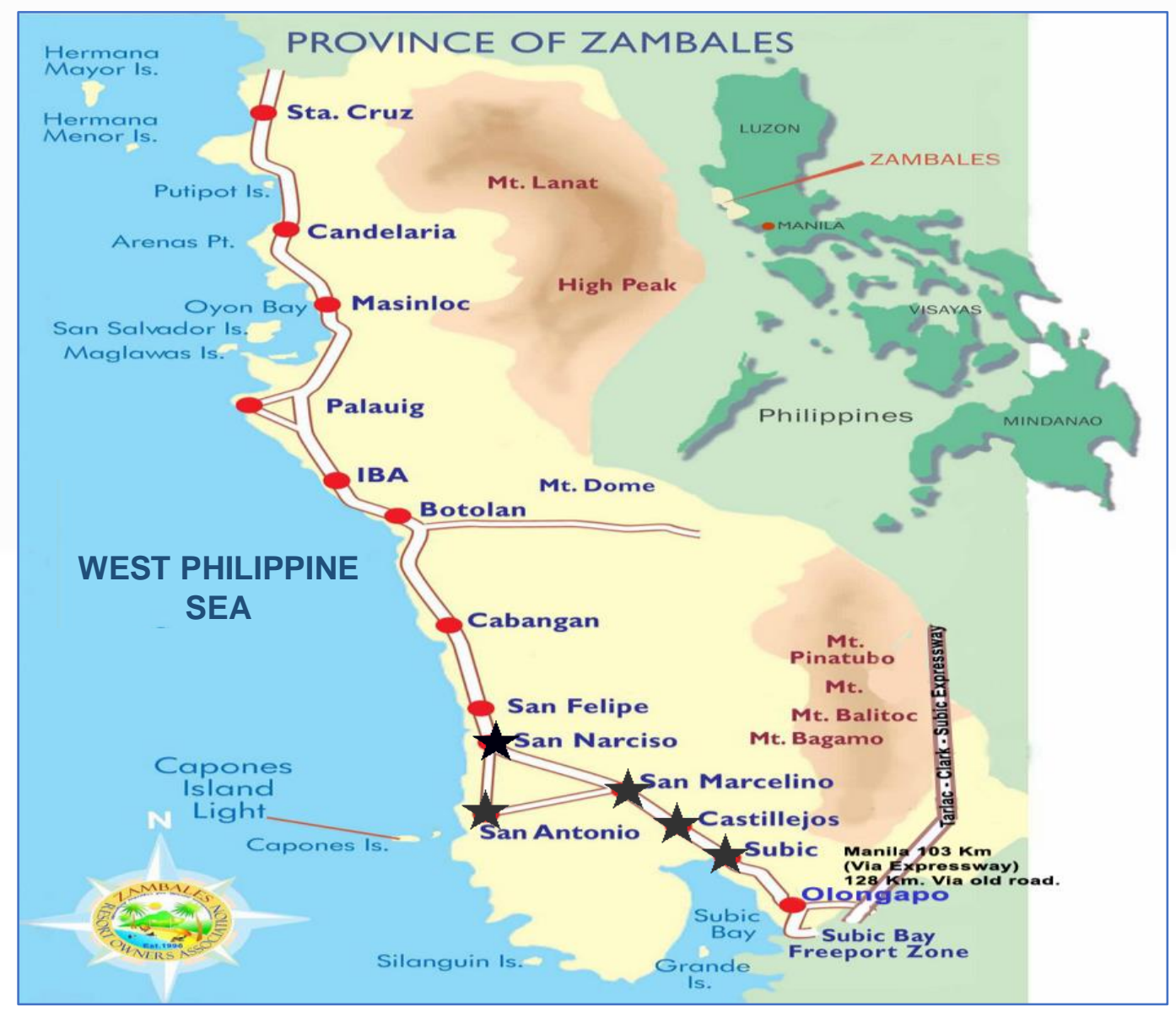

Figure 2. Map of Zambales, Central Luzon, Philippines 
ROGAYAN, Danilo Jr. V.; DOLLETE, Lea F. (2020) / Disaster Awareness and Preparedness of Barria...

Zambales is a province located in the Central Luzon (Region III) of the Philippine archipelago. The geographical coordinates are $15.5082^{\circ}$ North $(\mathrm{N})$, $119.9698^{\circ}$ East (E). Zambales borders the provinces of Pangasinan to the north and northeast, Tarlac to the east, Pampanga to the southeast, and Bataan to the south. The West Philippine Sea occurs on the western side of Zambales province. With a total area of $3,830.83 \mathrm{~km}^{2}$, Zambales is the second largest of the region's seven provinces. Zambales consists of 13 municipalities but only five municipalities were selected for the study (marked with stars in Figure 2). These towns are San Narciso $\left(15.0145^{\circ} \mathrm{N}, 120.0795^{\circ} \mathrm{E}\right)$, San Antonio $\left(14.9275^{\circ} \mathrm{N}\right.$, $\left.120.0896^{\circ} \mathrm{E}\right)$, San Marcelino $\left(15.0261^{\circ} \mathrm{N}, 120.2743^{\circ} \mathrm{E}\right)$, Castillejos (14.9438 $\mathrm{N}$, $\left.120.1936^{\circ} \mathrm{E}\right)$, and Subic $\left(14.8968^{\circ} \mathrm{N}, 120.2366^{\circ} \mathrm{E}\right)$.

With its strategic location, Zambales is prone to natural calamities and disasters. Common natural disasters include earthquakes, floods, typhoons and storm surges as well as volcanic eruptions. These natural disasters contribute to the damage of properties, and worst of all, claim peoples' lives.

\section{Study Group}

The study employed random sampling of 480 respondents from the five sites of southern Zambales. The respondents are members of the barrio communities and have resided in the area for at least two years. The respondents have different economic backgrounds. Their demographic profile is presented in Table 1.

Table 1

Demographic Profile of the Respondents

\begin{tabular}{lll}
\hline Profile & f & \% \\
\hline Age & 8 & 1.67 \\
$69-79$ & 17 & 3.54 \\
$60-69$ & 54 & 11.25 \\
$50-59$ & 69 & 14.38 \\
$40-49$ & 105 & 21.88 \\
$30-39$ & 124 & 25.83 \\
$20-29$ & 103 & 21.46 \\
$10-19$ & & \\
Gender & 258 & 53.75 \\
Male & 222 & 46.25 \\
Female & & \\
\hline Civil Status & 194 & 40.42 \\
Married & 261 & 54.38 \\
Single & 16 & 3.33 \\
Widow/er & 9 & 1.88 \\
Separated & & \\
\hline Municipality & 96 & 20.00 \\
Subic & 96 & 20.00 \\
Castillejos & 96 & 20.00 \\
San Marcelino & 96 & 20.00 \\
San Antonio & 96 & 20.00 \\
San Narciso & & \\
\hline
\end{tabular}

A majority of respondents belong to the age bracket of $20-29(25.83 \%)$ and 30 39 (21.88\%); they are mostly male (53.75\%) and are single (54.38\%). The barrio communities are equally distributed across five municipalities in southern Zambales. Most of the respondents who are in their early 20 s are studying at 
universities in the area. There are two campuses of a state university and two private colleges. The locale is both an agricultural and a coastal area so some respondents are skilled workers including farmers, tricycle drivers, vendors, carpenters and those who work in the fisheries. There also professionals who responded to the survey, for example teachers, entrepreneurs and medical professionals.

The present study did not include socio-economic status (SES) as a research variable because a data privacy law prohibits the enumerators to get such data without prior approval of the social welfare department. It is a time-consuming process to obtain approval and the time constraints associated with the study prevented the viability of gaining approval in a timely manner.

\section{Data Collection Tools}

A three-part Disaster Awareness and Preparedness Questionnaire (DAPQ) was developed by the researchers and its content were validated by three experts. The survey tool has three parts, namely:

(1) Demographic profile of the respondents;

(2) Disaster awareness; and

(3) Disaster preparedness level.

The concepts in the survey tool were lifted and modified from government websites which include the Philippine Institute of Volcanology and Seismology (Phivolcs), Philippine Atmospheric, Geophysical and Astronomical Services Administration (Pagasa) and National Disaster Risk Reduction and Management Council (NDRRMC) among others.

To assess the face validity and clarity of the survey instrument, it was preadministered among 50 non-respondents from the barrio communities. A general rule of thumb is to pilot the survey tool with between 30-100 participants although the quantity varies according to the number of respondents in the survey as a whole (Courtenay, 1978). The most effective pilot testing is always performed on a small sub-sample of the sample population so the pre-testing matches the cultural and demographic profile of the larger sample to be investigated (Ferketich, Philipps, \& Verran, 1993). On the other hand, Isaac and Michael (1995) and Hill (1998) suggested 10-30 participants for pilot-testing of survey tools while van Belle (2008) recommended 12 participants for the process. The respondents were asked to reflect on the survey questions and process during and after their survey. Following pilot testing, some minor changes to the DAPQ were made including elimination of redundant items in the different variables and adding items to better ascertain the intended purpose of the study.

The DAPQ recorded the following Cronbach's alpha values:

- Hazard level perception (0.83);

- Disaster awareness (0.88); and

- Disaster preparedness in strong typhoon (0.76), landslide (0.79), earthquake (0.81), fire (0.83), flood (0.86), and volcanic eruption (0.80).

The implication is that the different variables of the tool have acceptable to good reliability. Meanwhile, the overall Cronbach's alpha value is 0.83 which is 
ROGAYAN, Danilo Jr. V.; DOLLETE, Lea F. (2020) / Disaster Awareness and Preparedness of Barria...

interpreted as good reliability. Therefore, it is suggested that the instrument is reliable to be used for the study.

\section{Data Collection}

After securing approval from the barrio (barangays) communities of the selected Zambales municipalities, the respondents were asked to complete the survey questionnaire. The rationale of the study was fully clarified to the respondents. Informed consent was secured prior to the data collection. The survey took between 15 to 30 minutes to complete and translation of the difficult items into Filipino made it easier for barrio community members to understand. The survey tools were retrieved immediately after they were fully completed. The data collection occurred from May 2015 to January 2016.

\section{Data Analysis}

The data were analyzed using frequency counts and percent weighted mean. Pearson-R product correlation was carried out to measure the relationship of the respondents' disaster awareness and disaster preparedness. Data were treated using the Statistical Package for Social Sciences (SPSS) software version 20. The five-point rating scale interpretation of the perceived hazard level of the disasters, and the extent of disaster awareness and disaster preparedness is shown in Table 2.

\section{Table 2}

Likert Scale Interpretation

\begin{tabular}{lllll}
\hline Scale & $\begin{array}{l}\text { Mean Rating } \\
\text { Interval }\end{array}$ & $\begin{array}{l}\text { Perceived Hazard } \\
\text { Level of Disasters }\end{array}$ & $\begin{array}{l}\text { Extent of Disaster } \\
\text { Awareness }\end{array}$ & $\begin{array}{l}\text { Disaster Preparedness } \\
\text { Level }\end{array}$ \\
\hline 5 & $4.50-5.00$ & Devastating & Highly Aware & Always \\
4 & $3.50-4.49$ & Very Destructive & Very Aware & Often \\
3 & $2.50-3.49$ & Destructive & Moderately Aware & Sometimes \\
2 & $1.50-2.49$ & Strong & Slightly Aware & Seldom \\
1 & $1.00-1.49$ & Weak & Totally Unaware & Never \\
\hline
\end{tabular}

\section{Findings}

\section{Common Disasters Experienced by Members of the Barrio Communities}

Table 3 presents the common disasters experienced by respondents from the barrio communities. As gleaned from the table, a majority of the respondents have experienced a strong typhoon (88.33\%). This corroborates to the fact that the country is a frequent area for typhoons.

Table 3

Common Disasters Experienced by Respondents

\begin{tabular}{llll}
\hline Disaster & $\mathbf{f *}^{*}$ & $\%$ & Rank \\
\hline strong typhoon & 424 & 88.33 & 1 \\
landslide & 118 & 24.58 & 5 \\
earthquake & 290 & 60.42 & 2 \\
fire & 79 & 16.46 & 7 \\
tsunami & 23 & 4.79 & 8 \\
flood & 231 & 48.13 & 3 \\
storm surge & 86 & 17.92 & 6 \\
volcanic eruption & 190 & 39.58 & 4 \\
\hline
\end{tabular}

*multiple-response 
Likewise, the respondents have also experienced earthquakes (60.42\%), floods $(48.13 \%)$ and volcanic eruptions (39.58\%). Most of the respondents surveyed are victims of the June 1991 Mt. Pinatubo volcanic eruption which ravaged not only Zambales but also the neighboring provinces of Central Luzon. Meanwhile, only a few respondents from the barrio communities experienced a storm surge (17.92\%), fire (16.46\%) and tsunami's (4.79\%). Among those from the municipalities surveyed, only Subic, San Antonio and San Narciso can be classified as coastal towns so that suggests why only few respondents also have experienced coastaldriven disasters like tsunamis and storm surges.

\section{Common Disasters Experienced by Members of the Barrio Communities}

The perceptions of respondents about the hazard levels of the given disasters are presented in Table 4 . The respondents from barrio communities perceived typhoons as very destructive $(M=3.56)$. The emergence of a strong typhoon in the province of Zambales for the past decade left an unforgettable impact to the residents.

Table 4

Hazard Level of Disasters as Perceived by Members of the Barrio Communities

\begin{tabular}{lllll}
\hline Disaster & Mean & SD & Qualitative Interpretation & Rank \\
\hline strong typhoon & 3.56 & 1.18 & Very Destructive & 1 \\
landslide & 2.64 & 1.58 & Destructive & 5 \\
earthquake & 2.75 & 1.33 & Destructive & 4 \\
fire & 2.50 & 1.47 & Destructive & 6 \\
tsunami & 2.25 & 1.78 & Strong & 7 \\
flood & 2.86 & 1.61 & Destructive & 3 \\
storm surge & 2.22 & 1.48 & Strong & 8 \\
volcanic eruption & 3.13 & 1.46 & Destructive & 2 \\
\hline
\end{tabular}

The respondents perceived volcanic eruption $(M=3.13)$, flood (2.86), earthquake $(M=2.75)$, landslide $(M=2.64)$ and fire $(M=2.50)$ as destructive disasters in terms of the hazard level. Meanwhile, tsunami $(M=2.25)$ and storm surge $(M=2.22)$ are perceived as strong disasters.

\section{Extent of Disaster Awareness amongst members of the Barrio Communities}

The levels of awareness about the nature, impact and threats of various disasters from the barrio communities are presented in Table 5. The Zambaleños (residents of Zambales) are very aware on the repercussions of strong typhoon $(M=3.77)$ as they frequently experience this disaster in their locality. Meanwhile, the following are all rated as moderately aware by the respondents: flood $(M=3.31)$, volcanic eruption $(M=3.30)$, earthquake $(M=3.12)$, landslide $(M=2.96)$, fire $(M=2.83)$, storm surge $(M=2.70)$ and tsunami $(M=2.69)$.

Table 5

Disaster Awareness from members of the Barrio communities

\begin{tabular}{lllll}
\hline Disaster & Mean & SD & Qualitative Interpretation & Rank \\
\hline strong typhoon & 3.77 & 1.22 & Very Aware & 1 \\
landslide & 2.96 & 1.38 & Moderately Aware & 5 \\
earthquake & 3.12 & 1.39 & Moderately Aware & 4 \\
fire & 2.83 & 1.66 & Moderately Aware & 6 \\
tsunami & 2.69 & 1.70 & Moderately Aware & 8 \\
flood & 3.31 & 1.46 & Moderately Aware & 2 \\
storm surge & 2.70 & 1.50 & Moderately Aware & 7 \\
volcanic eruption & 3.30 & 1.29 & Moderately Aware & 3 \\
\hline
\end{tabular}


ROGAYAN, Danilo Jr. V.; DOLLETE, Lea F. (2020) / Disaster Awareness and Preparedness of Barria...

\section{Extent of Disaster Preparedness from members of the Barrio Communities}

The disaster preparedness of barrio communities is presented in Table 6. Disaster preparedness is defined as the knowledge and capabilities developed by states, professional recovery and response agencies, communities and individuals to efficiently foresee, adapt and recover from the impacts of probable, imminent or current danger events or circumstances (Commission on Audit, 2014).

Table 6

Disaster Preparedness from members of the Barrio Communities

\begin{tabular}{lllll}
\hline Disaster & Mean & SD & Qualitative Interpretation & Rank \\
\hline strong typhoon & 3.91 & 0.21 & Often & 1 \\
landslide & 3.57 & 0.20 & Often & 4 \\
earthquake & 3.50 & 0.14 & Often & 6 \\
fire & 3.54 & 0.21 & Often & 5 \\
flood & 3.84 & 0.19 & Often & 2 \\
volcanic eruption & 3.68 & 0.19 & Often & 3 \\
\hline
\end{tabular}

Strong Typhoon. The village settlers often prepare for strong typhoon ( $M=3.91)$. They mostly prepare by charging their cellphone. Communication tools like cellular phones cannot only be used for calling or sending short messaging system (SMS) but also for browsing updates through social media and news websites. Moreover, the respondents from barrio communities also indicated they prepare by organizing flashlights and first aid kits, and by listening to radio for updates about the typhoon movement. Respondents also prepare for a strong typhoon by organizing at least a three-day supply of water and food. The least observed practices are checking disaster supplies and learning about community's storm response plan.

Landslide. Responses from members of the barrio communities indicate they 'often practice' preparedness against landslides $(M=3.57)$. They will often familiarize themselves with the land where they live and work so they will understand the risk in different situations. Likewise, if they suspect imminent danger, evacuation occurs immediately. The least number of respondents say they prepare against landslide by creating and practicing an evacuation plan for their respective families. Several landslides have happened in the locale which contributed to economic damage and life loss. Thus, the community people are becoming more conscious about landslide preparedness.

Earthquake. Responses from members of the barrio communities indicate their disaster preparedness for earthquakes is classified as 'often practiced' ( $M=3.50)$. The respondents also 'often practice' familiarizing themselves with all of the buildings they inhabit for fire evacuation and earthquake plans. Respondents also keep a flashlight and durable shoes near the bed of every person $(M=3.78)$. Furthermore, the respondents from barrio communities 'often practice' staying indoors until the trembling ends to make sure it is safe to exit with heavy objects.

Fire. Responses from members of the barrio communities indicate they 'often practice' fire disaster preparedness ( $M=3.54)$. They will 'often practice' teaching kids about fire risks, storing matches and lighters and keeping them out of reach. Respondents also often keep anything that is flammable at least three feet away from everything that gets hot. Also, the barrio community members 'sometimes 
practice' teaching household members to stop, drop and roll if their clothes catch on fire and practice an escape drill at least twice a year from their house during various times of the day.

Flood. Responses from members of the barrio communities about floods indicate, preparedness is 'often practiced' $(M=3.84)$. The respondents ensure they are especially vigilant at night when it is more difficult to detect flood danger. When a flood warning or flash flood alert is announced for their area, they head up to the higher ground and stay there. The least observed practices mentioned by respondents include being prepared to leave at a moment's notice, and turning around to head in a different direction if they are driving on a flooded road.

Volcanic Eruption. Responses from members of barrio communities indicate they 'often practice' preparedness for volcanic eruptions $(M=3.68)$. This disaster ranked highest among the preparedness activities. Strategies adhered to by the respondents included staying out of designated restricted zones and following any evacuation orders issued by authorities. The activities less observed by respondents include developing an evacuation plan for volcanic eruptions for their family, and reviewing with members of their household any security and contingency plans available for landslides and mudflows. This suggests that the local government units must craft community evacuation plans to be publicly posted in strategic locations around the community to further enhance people's preparedness for a volcanic eruption.

\section{Relationship between Disaster Awareness and Preparedness}

The Pearson-R correlation was calculated to check if a significant correlation exists between disaster awareness and disaster preparedness amongst the barrio community (Table 7).

Table 7

Correlation between Disaster Awareness and Disaster Preparedness of Barrio Communities

\begin{tabular}{lll}
\hline Variables & $\mathbf{R}$ & p-value \\
\hline Disaster Awareness & $0.449^{*}$ & 0.035 \\
\hline Disaster Preparedness & & \\
\hline
\end{tabular}

*Correlation significant at 0.01

As shown in the table, the computed Pearson correlation coefficient $(r)$ was $0.449(p=0.035)$ which means a moderate positive correlation exists between levels of disaster awareness and disaster preparedness among the barrio communities in southern Zambales, Philippines.

\section{Proposed Curricular Integration and Community Extension Program}

Table 8 lists the possible topics/subject matter that may be integrated into the curriculum for teacher education programs. 
ROGAYAN, Danilo Jr. V.; DOLLETE, Lea F. (2020) / Disaster Awareness and Preparedness of Barria...

Table 8

Proposed Topics/Subject Matter for Integration in the Curriculum

\begin{tabular}{ll}
\hline Subject/ Course & Topic/Subject Matter \\
\hline Environmental Science & Disaster Science Management Concepts \\
Ecology & Effects of Disasters on Biodiversity \\
Filipino / English & Translation of Disaster Concepts and Terms \\
NSTP & Community-Based Disaster Response \\
Social Sciences & Republic Act 10121: Overview of the Law' \\
Geography & Geography Literacy and the Disasters \\
P.E. and Health & First Aid and Injury Prevention during Disaster \\
Scientific and Technical Writing & DevCom writing on disaster risk reduction \\
Educational Technology & IMs on disaster risk reduction \\
Social Dimensions of Education & Environmental Sustainability \\
Special Topics in Education & UN Sustainable Development Goals \\
\hline
\end{tabular}

'Philippine Disaster Risk Reduction and Management (DRRM) Act of 2010

These topics were identified by the researchers so that students in college will become more aware of disaster risk, its management and its risk-reduction. The proposed topics for integration are drawn from the lowest ratings indicated by the respondents in the survey. The curricular integration is multidisciplinary in nature and includes the natural sciences, languages, education, social sciences, and health sciences. Based on the survey findings, a proposed community extension program is presented in Table 9. The proposed extension program of the university is titled k-ALAM-idad 101: Disaster Awareness and Preparedness Drive. "Kalamidad" is a Filipino term for disaster while the word "alam" means knowledge. The program has four components namely the development of materials for information, education and communication (IEC) such as film viewing, simulations and workshops, and leadership of team-building activities. All these components are anchored on the objective of increasing the levels of awareness and preparedness about disaster risk reduction amongst the barrio communities.

Table 9

Proposed Community Extension Program k-ALAM-idad 101: Disaster Awareness and Preparedness Drive

\begin{tabular}{|c|c|c|c|c|}
\hline Objective & Activities/ Topics & Persons Involved & $\begin{array}{l}\text { Target } \\
\text { Date }\end{array}$ & $\begin{array}{l}\text { Expected } \\
\text { Output }\end{array}$ \\
\hline $\begin{array}{l}\text { Component 1: Proje } \\
\text { Develop localized, } \\
\text { indigenized } \\
\text { information } \\
\text { education and } \\
\text { communication } \\
\text { (IEC) materials on } \\
\text { disaster science } \\
\text { management }\end{array}$ & $\begin{array}{l}\text { IEC Material } \\
\text { Crowdsourcing of } \\
\text { ideas } \\
\text { Development and } \\
\text { validation of localized, } \\
\text { contextualized and } \\
\text { indigenized disaster } \\
\text { flyers, brochures } \\
\text { and/or pamphlets }\end{array}$ & $\begin{array}{l}\text { NDRRMC, DOST, } \\
\text { CHED, LGUs, } \\
\text { Experts in the } \\
\text { University, } \\
\text { Researcher, } \\
\text { Faculty \& Staff, } \\
\text { Students, } \\
\text { Community } \\
\text { People }\end{array}$ & $\begin{array}{l}\text { June to } \\
\text { July }\end{array}$ & $\begin{array}{l}\text { Developed } \\
\text { IEC materials } \\
\text { Research } \\
\text { output }\end{array}$ \\
\hline \multicolumn{5}{|c|}{ Component 2: Project Edulikula } \\
\hline $\begin{array}{l}\text { Educate the } \\
\text { community on the } \\
\text { nature, possible } \\
\text { effects, extent of } \\
\text { damage, and }\end{array}$ & $\begin{array}{l}\text { Conduct of film } \\
\text { viewing about } \\
\text { disasters. } \\
\text { Distribution of IEC } \\
\text { materials }\end{array}$ & $\begin{array}{l}\text { NDRRMC, LGUs, } \\
\text { NGOs, Experts in } \\
\text { the University, } \\
\text { Researcher, } \\
\text { Faculty \& Staff, }\end{array}$ & $\begin{array}{l}\text { August } \\
\text { to } \\
\text { Octobe } \\
r\end{array}$ & $\begin{array}{l}\text { Attendance } \\
\text { sheet of } \\
\text { participants, } \\
\text { monthly } \\
\text { monitoring }\end{array}$ \\
\hline
\end{tabular}




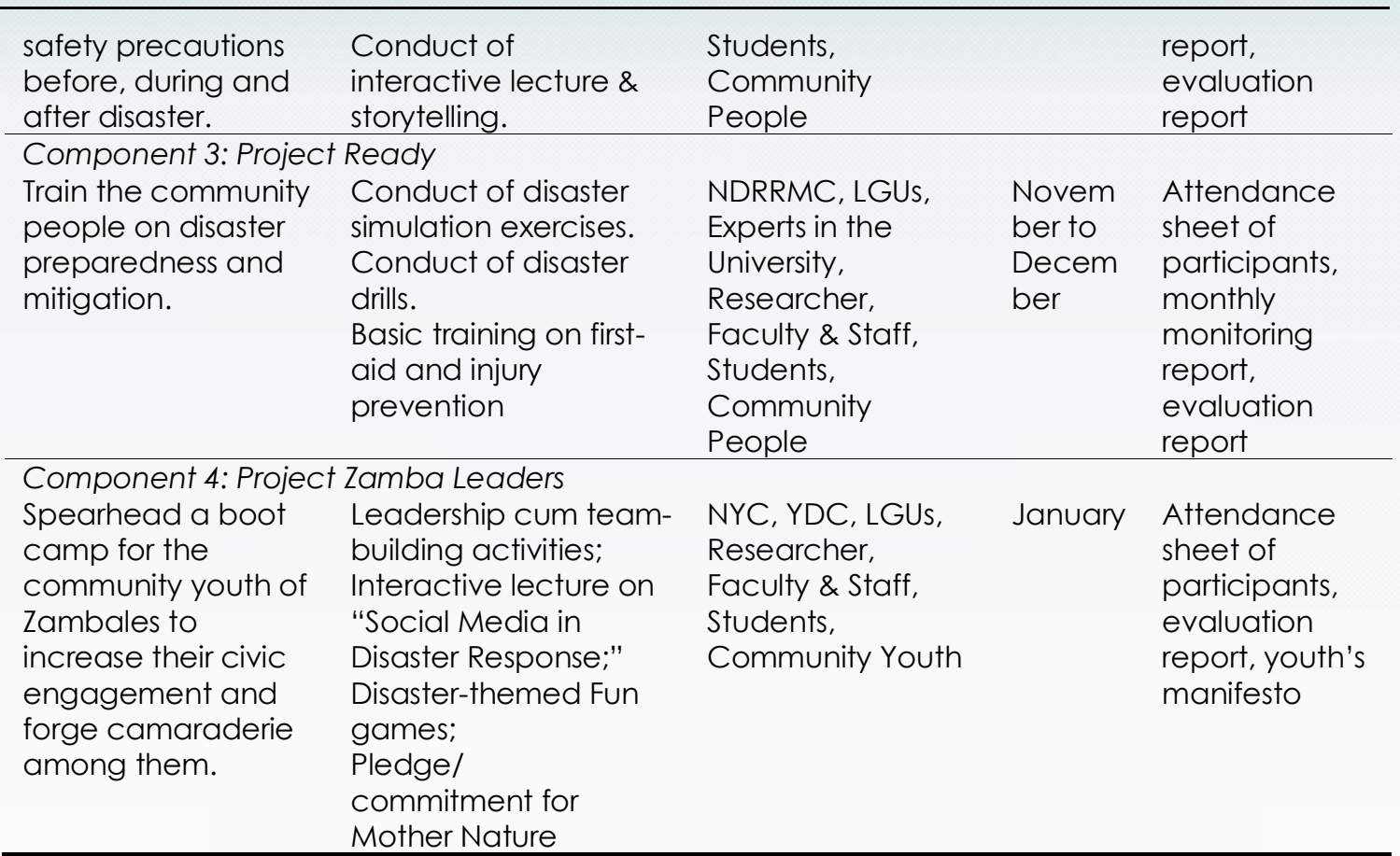

Note. NDRRMC (National Disaster Risk Reduction and Management Council), DOST (Department of Science and Technology), CHED (Commission on Higher Education), LGUs (Local Government Units), NGOs (Non-Governmental Organizations), NYC (National Youth Commission), YDC (Youth Development Council)

\section{Discussion}

The research findings from the current study ascertains the extent of disaster awareness and disaster preparedness occurring amongst members of the barrio communities in southern Zambales. From the first research question, it was determined there are many hazards experienced by the locals which threaten the ecological communities; hence, disaster preparedness must be everyone's concern. Jackson, McNamara, and Witt (2017) argued that individuals and families in a society have varying rates of susceptibility to disasters that influence how they plan for, adapt to, and recover from a disaster.

The results of analysis for the second research question showed that tsunamis and storm surges were given an average rating of hazard level because the majority of respondents have not experienced these disasters themselves. This implies that the most frequent disasters occurring in the community are perceived to be hazardous.

Based on data in the World Risk Report (2018), the Philippines ranked third among the world's highest disaster-prone countries with an index value of $25.14 \%$ (World Economic Forum, 2018). At least $60 \%$ of the total land area in the Philippines is susceptible to numerous risks, and $74 \%$ of the populace is vulnerable to their effects (Global Facility for Disaster Reduction and Recovery, 2017). The location and geographic context of the Philippines means the coastal danger risk (e.g. typhoons, storm surge, increasing sea levels) is high. 
From the third research question, it can be inferred the majority of respondents are not fully aware about the nature, impact and threats of most of disasters they have experienced. This may be due to the fact they only frequently experience only one or two disasters such as typhoon and earthquake. Other disasters which have not been recently experienced could possibly have contributed to the low rating about disaster awareness because disaster experience promotes disaster awareness (Hoffmann, \& Muttarak, 2017). Availability of information has also been identified as another impediment to the awareness levels identified by those involved in the study. It should also be noted that tsunami's and storm surges were given the lowest means because these two disasters do not frequently happen in the barrio communities. Even though some disasters have not happened recently, it is still important for members of the Barrio communities to be aware about them.

Parallel to this, the Commission on Audit (2014) reiterated that the overall vision of Filipino societies for sustainable development is healthy, adaptive and resilient to disasters. The report presents a paradigm shift from passive to proactive regarding disaster risk reduction management (DRRM). In so doing, men and women have increased their levels of knowledge and understanding about DRRM with the goal of raising the resilience of people and reducing their vulnerabilities as embedded in the national framework.

Collaborative initiatives involving different groups such as government, the private industry, community and civil society organizations, should provide information to protect vulnerable populations during times of disaster, and strengthen their disaster preparedness and responses (Malik et al., 2019). In the same vein, Teo, Goonetilleke, Ahankoob, Deilami, and Lawie (2018) stated that the socio-economic status of the people may increase their susceptibility to, ability to brace for, and capacity to recuperate after, a disaster. The research team reiterated that people from low socio-economic backgrounds frequently face higher disaster threats but are less equipped for disaster events due to factors including lack of available low-cost accommodation, receipt of low wages and rates of low literacy.

Results of analysis from the fourth research question show that respondents from the barrio communities are often prepared for different disasters. For tropical storms with shorter return periods, the common experience of such disaster also contributes to improved preparation levels, including an increased awareness about the disaster and a safer infrastructure provision to protect against the outcomes of potential disaster events (Esteban et al., 2015; Leelawat, Mateo, Gaspay, Suppasri, \& Imamura, 2014). From time immemorial, the Philippines has been plagued by several destructive storms and other natural and man-made disasters both at the storm belt and the Pacific Ring of Fire due to its geographical location. The country is also vulnerable to several other frequent hazards including cyclones, landslide, floods, and earthquakes (Bacal et al., 2013).

The effect of geography on peoples' lives should also be considered in disaster preparedness strategies. Hence, emphasis on the teaching of geography to students and the community, as part of a disaster education campaign must occur. This aligns with the claims of Kamil, Utaya, \& Utomo (2020) who suggest 
that teachers should be expected to utilize instructional resources based on geographical context to promote disaster risk reduction education. Thus, students will have good emergency management skills and are able to find solutions to natural devastation and minimize its negative impacts. People's knowledge about geography is as important as being aware of the disasters.

In the same vein, there is an association between the occurrence of natural disasters and the geographical settings under which they occur. Thus, literacy in geography is a significant platform to provide knowledge about disasters (Susanto, Sumarmi \& Susilo, 2016). Disasters have been documented in various parts of the Philippines throughout history. The geology of the country describes the prevalence of earthquakes, tsunami's, landslides, and other calamities (Commission on Audit, 2014).

For fire preparedness, the potential effect of fire on human health and the economic harm resulting from this disaster have shown the significance of mastering emergency response strategies for housing infrastructures and healthcare infrastructure in the communities (Bongiovanni, Leo, Ritrovato, Santoro, \& Derrico, 2017). Meanwhile, the hydro-meteorological phenomena, including typhoons and floods, accounted for more than $80 \%$ of natural calamities in the last half-century in the Philippines (Jha, Martinez, Quising, Ardaniel, \& Wang, 2018). Therefore, a higher degree of preparedness must be strengthened among the people's practices with the support of the government and other stakeholders.

As the Philippine islands are located within the Pacific Ring of Fire between the Eurasian and Pacific tectonic plates, earthquakes and volcanoes pose significant risks to the heath of the community (Office for Disaster Risk Reduction, UN, 2019).

Conclusively, results from the current study about the disaster preparedness of barrio communities imply that those living in the barrios should be encouraged to prepare for different disasters that might strike the locality. Over the years, different strategies have been adopted by the Philippines from disaster preparedness and response (1970s), disaster management (1980s), disaster risk management (1990s), and finally disaster risk reduction (2005 and beyond) (Commission on Audit, 2014). No community is resistant to catastrophe and it is essential to devise and implement a range of effective disaster preparedness and disaster mitigation plans and services to safeguard the well-being of the community and help develop social resilience to disasters (Saja, Teo, Goonetilleke, \& Ziyath, 2018).

Findings related to the next research question show that as the level of disaster awareness increases, the level of disaster preparedness will also increase. Such a finding highlights the need to intensify the teaching of disaster science management and the need to disseminate information to the community people through extension activities. The findings of the study are supported by several studies on disaster awareness and preparedness (Fujii, \& Kanbara, 2019; Matsumoto, Sasaki, \& Muslim, 2018; Ozeki, \& Ojima, 2019; Teo et al., 2018). The implication is that being aware about disaster-risk can be a significant precursor to being prepared in times of these unfortunate events. Further, public awareness 
of hazards is affected by different types of disasters and prior exposure to previous disasters (Ho et al., 2008 as cited in AlQahtany, \& Abubakar, 2020).

For the last research question about the proposed curricular integration and extension programs, the proposed topics for integration in the curriculum and the proposed extension program were based on the lowest ratings indicated by the respondents in the survey questionnaire. Disaster awareness can be further harnessed through formal education especially for the Generation Z learners who will guide more people in the barrio communities. This can only be attained through the active and consistent participation of all stakeholders concerned (Khorram-Manesh et al., 2016; Wang, 2016).

The universities and colleges are challenged to develop learners who have strong and proactive environmental stewardship through its curriculum and instruction (Rogayan, 2019). In the Philippines, one of the goals of science education is to produce students who are environmentally-aware and are conscious about their actions towards sustainable development (Rogayan \& Nebrida, 2019). With the proposed topics for integration, it is hoped that the students will become more aware and more conscious about disasters and may increase their degree of preparedness.

Science has also become a very powerful weapon to examine, explore and discover new ideas and concepts that are important in the today's milieu through the advancement of technology (Macanas \& Rogayan, 2019). Hence, the use of technological tools and science-based approaches towards teaching disaster management can be harnessed to develop disaster-ready communities. Furthermore, Kamil et al. (2020) mentioned the achievement of learning should encourage learners to take action and suggest solutions to help build their levels of disaster preparedness.

The proposed community extension program is in consonance with the disaster risk interventions in the Philippines as reported by the Office of Civil Defense - National Disaster Risk Reduction and Management Council (2015). Structural and non-structural activities are carried out at a local level which includes infrastructure for risk reduction, equipment procurement, stockpiling of basic emergency relief supplies, training, planning, capability building including, information, education and communication (IEC) material development, and risk management mechanisms among others.

The knowledge of disaster management can be attained by teaching the communities about disasters (Kamil et al, 2020). Providing knowledge about disaster management is the key towards successful management of these natural and man-made hazards. The dimensions of the damage which may occur as a result of disasters tend to be very high for both humans and the ecosystem. Therefore, every community needs to have a disaster action plan and give priority to these efforts to minimize losses and sustain daily life (Dikmenli, Yakar \& Konca, 2018).

\section{Conclusion}

The results from the current study have determined the levels of disaster awareness and disaster practices amongst members from barrio communities. Respondents have encountered numerous disasters like strong typhoon, 
earthquake, flood and volcanic eruption. Their lived experiences taught them to be prepared and equipped for possible disasters that might occur. Furthermore, their lived experiences encouraged them to practice disaster preparedness.

Moreover, the people from Zambales barrio's perceived typhoons as 'very destructive'; and volcanic eruption, flood, earthquake, landslide and fire as 'destructive'; whereas they perceived tsunami's and storm surges as 'strong'. The perceptions of the respondents are based on their lived experiences and also from their understanding gained from information they obtained from the media including television, radio and newspapers. In terms of disaster awareness, Zambaleños are very aware about the repercussions of 'strong' typhoons and are moderately aware about floods, volcanic eruptions, earthquakes, landslides, fire, storm surges and tsunamis. Making the barrio communities more aware about the different disasters will not only save lives but will also save the economy.

As for disaster preparedness, the respondents say they are often prepared in 'strong' typhoons, floods, volcanic eruptions, landslides, fire and earthquakes. Their preparedness is related to their understanding gained from the advice received about local disaster risk reduction and management task forces from news advisories and information coming from the university.

The results of the study have several important implications. Since the Zambales province has experienced several disasters in the past decade, it is important to further strengthen people's levels of awareness and preparedness. One of the disasters experienced by those living in Zambales province is the notorious Mount. Pinatubo eruption in 1991. The volcanic explosion incurred $\$ 700$ million worth of damage, of which $\$ 100$ million related to the devastation of 16 aircraft flying at the time of the event, and $\$ 250$ million related to property values form agriculture, forestry and land (Geological Survey, 2015). Another disaster experienced by those living in Zambales province was the Luzon Earthquake. The earthquake happened in 2019 and had a magnitude of 6.1; the epicenter was in the town of Castillejos. The NDRRMC reported damage to at least 29 buildings and other structures, including the Clark International Airport (Mogato, 2019). Another disaster occurred when a total of 22 people was killed in the province of Zambales due to a landslide in 2013 which happened during the Super Typhoon Odette, which is also known by its international name Usagi (Sison, 2013). In 2018, a total of 1,605 families, comprising 5,520 individuals, were relocated from 9 towns across the Zambales province due to Typhoon Ompong which is also known by its international name Mangkhut (Datu, 2018).

In view of these disasters, the extent of disaster awareness and disaster preparedness demonstrated by the barrio communities about disaster risk may serve as baseline information to inform decisions about the integration of disaster science and management in the curriculum, specifically into other non-science disciplines across the higher education curriculum. The incorporation of disaster management and disaster preparedness in the different curricular programs in the academe would eventually help not only students but also the community as a whole in how they would deal with the threats and risks of disasters affecting their respective communities. The perceptions and practices of the barrio communities may also serve as an input for a community extension program of the university. The lone state-owned university in the province is tasked not only 
to provide instruction and undertake research but also to transfer new knowledge and information to the community. The proposed extension program is recommended for implementation by the university. This extension program is composed of several components such as an information dissemination campaign through workshops and symposia, production of disaster information brochures, and posting of disaster preparedness information. Strengthening the information dissemination activities is critical in developing a heightened degree of awareness about disaster and lessen the risks occurring from disasters.

Furthermore, the baseline data could serve as an impetus for strengthening policy implementation around national laws such as Republic Act (RA) No. 9729 (Climate Change Act of 2009) and RA 10121 (Philippine Disaster Risk Reduction and Management Act of 2010). Such policies aim to improve the resilience of vulnerable communities and the nation to natural catastrophes, and to minimize disaster-related harm including loss of life and damage to property. The university could partner to Local Government Units (LGUS) and Non-Government Organizations (NGOs) for this purpose. Technical support for LGUs from national governments, academic institutions and DRRM experts is hereby recommended in order to tangibly enforce DRRM activities at local level. Disaster management entails cooperative and collaborative action; thus, stakeholders' partnership must be strengthened.

\section{Acknowledgement}

The authors would like to extend their sincerest gratitude to the community people from the five municipalities for the willingness to take part in this research endeavor, to the enumerators who painstakingly gathered the needed data and to the President Ramon Magsaysay State University (PRMSU) for the support.

\section{References}

Abugho, D.E., Angeles, J.B., \& Dacayo, N.A. (2016). Disaster science and management of three southern coastal barangays of Botolan, Zambales. International Journal of Interdisciplinary Research and Innovations, 4(4), 1-13).

Ahayalimudin, N., \& Osman, N. N. S. (2016). Disaster management: Emergency nursing and medical personnel's knowledge, attitude and practices of the East Coast region hospitals of Malaysia. Australasian Emergency Nursing Journal, 19(4), 203209. https://doi.org/10.1016/j.aenj.2016.08.001

AIQahtany, A. M., \& Abubakar, I. R. (2020). Public perception and attitudes to disaster risks in a coastal metropolis of Saudi Arabia. International Journal of Disaster Risk Reduction, 44, 101422. https://doi.org/10.1016/j.ijdrr.2019.101422

Amaratunga, D., Malalgoda, C., Haigh, R., Panda, A., \& Rahayu, H. (2018). Sound practices of disaster risk reduction at local level. Procedia engineering, 212, 1163 1170. https://doi.org/10.1016/j.proeng.2018.01.150

Bacal, C., Carcellar, N., Dagondon, B., Enriquez, J., Temprosa, F., Ginnetti, J., \& Villanueva, C. (2013). Disaster-induced displacement in the Philippines: The case of tropical storm Washi/Sendong. Internal Displacement Monitoring Centre, Geneva. https://doi.org/10.1163/2210-7975_hrd-9806-3005

Baytiyeh, H., \& Ocal, A. (2016). High school students' perceptions of earthquake disaster: A comparative study of Lebanon and Turkey. International Journal of Disaster Risk Reduction, 18, 56-63. https://doi.org/10.1016/j.ijdrr.2016.06.004 
Bongiovanni, I., Leo, E., Ritrovato, M., Santoro, A. and Derrico, P. (2017). Implementation of best practices for emergency response and recovery at a large hospital: A fire emergency case study. Safety Science, 96, 121-131. https://doi.org/10.1016/j.ssci.2017.03.016

Causapin, H. P. A. (2018). Semi-Markov chain modeling on earthquake occurrences in selected areas in Luzon. Tilamsik: The Southern Luzon Journal of Arts and Sciences, 10, 67-90.

Cinco, T. A., de Guzman, R. G., Ortiz, A. M. D., Delfino, R. J. P., Lasco, R. D., Hilario, F. D., \& Ares, E. D. (2016). Observed trends and impacts of tropical cyclones in the Philippines. International Journal of Climatology, 36(14), 4638-4650. https://doi.org/10.1002/joc.4659

Commission on Audit. (2014). Disaster management practices in the Philippines: An Assessment. Retrieved from https://www.coa.gov.ph/disaster_audit/doc/National.pdf

Courtenay, G. (1978). Questionnaire Construction. In Hoinville, G., and Jowell, R., Survey Research Practice (chapter 3). Heinemann Educational Books: London.

Creswell, J. W. (2005). Educational research: Planning, conducting, and evaluating quantitative and qualitative research. Upper Saddle River, NJ: Pearson Education.

Datu, R. (2018, September 15). 1,605 families in 9 Zambales towns evacuate during Typhoon Ompong. Rappler. Retrieved from https://www.rappler.com/nation/212069-families-evacuated-zambales-typhoonompong

De Viana, A. V. (2016). The Philippines' typhoon alley: The historic bagyos of the Philippines and their impact. Jurnal Kajian Wilayah, 5(2), 184-216.

Department of Disaster Management - Virgin Islands. (2011). Community disaster preparedness handbook. Tortola, Virgin Islands: Department of Disaster Management.

Dikmenli, Y., Yakar, H. \& Konca, A. (2018). Development of disaster awareness scale: A validity and reliability study. Review of International Geographical Education Online, 8(2), 206-220.

Djalante, R., Garschagen, M., Thomalla, F., \& Shaw, R. (2017). Disaster Risk Reduction in Indonesia. Fujisawa, Japan: Springer. https://doi.org/10.1007/978-3-319-54466-3

Dobrucali, E., \& Demir, I. H. (2016). Earthquake and flood disaster management regulations in Turkey. Disaster Science and Engineering, 2(1), 1-6.

Doroteo, H. J. E. (2015). Philippines: Disaster Risk Profile and Disaster Risk Reduction (DRR) Framework: Natural Disasters. Asturias, Spain: University of Oviedo.

Ersoy, S., \& Kocak, A. (2016). Disasters and earthquake preparedness of children and schools in Istanbul, Turkey. Geomatics, Natural Hazards and Risk, 7(4), 1307-1336. https://doi.org/10.1080/19475705.2015.1060637

Esteban, M., Valenzuela, V. P., Yun, N. Y., Mikami, T., Shibayama, T., Matsumaru, R., \& Nakamura, R. (2015). Typhoon Haiyan 2013 evacuation preparations and awareness. International Journal of Sustainable Future for Human Security, 3(1), 3745.

Farin, E.N., Co, A.I., \& Farin, A.N. (2017). Flood disaster preparedness and practices of the public elementary schools in selected flood - prone areas in Zambales, Philippines. International Journal of Social Science and Humanities Research, 5(1), 97-108. 
ROGAYAN, Danilo Jr. V.; DOLLETE, Lea F. (2020) / Disaster Awareness and Preparedness of Barria...

Ferketich, S., Phillips, L., \& Verran, J. (1993). Development and administration of a survey instrument for cross-cultural research. Research in Nursing \& Health, 16(3), 227-230. https://doi.org/10.1002/nur.4770160310

Fernandez, G., \& Shaw, R. (2015). Youth participation in disaster risk reduction through science clubs in the Philippines. Disasters, 39(2), 279-294. https://doi.org/10.1111/disa.12100

Fujii, M., \& Kanbara, S. (2019). Analysis of gender differences in disaster preparedness for Nankai trough earthquake. Health science Journal, 13(2), 1-4. https://doi.org/10.21767/1791-809X.1000644

Geological Survey (US). (2015). Pinatubo 1991. Retrieved from https://volcanoes.usgs.gov / volcanic_ash/about_us.html

Global Facility for Disaster Reduction and Recovery. (2017). GFDRR: Philippines. Retrieved from https://www.gfdrr.org/en/philippines

Hill, R. (1998). What sample size is "enough" in internet survey research? Interpersonal Computing and Technology: An Electronic Journal for the 21 st Century, 6(3-4), 112.

Hoffmann, R., \& Muttarak, R. (2017). Learn from the past, prepare for the future: Impacts of education and experience on disaster preparedness in the Philippines and Thailand. World Development, 96, 32-51. https://doi.org/10.1016/j.worlddev. 2017.02.016

Ilo, P.I., Izuagbe, R., Mole, A.J.C. \& Ekwueme, L. (2018). Measuring disaster preparedness and response practices in university libraries in Nigeria: The role of disaster equipment. International Journal of Disaster Risk Reduction, 31, 85-91. https://doi.org/10.1016/j.ijdrr.2018.04.007

Isaac, S., \& Michael, W. B. (1995). Handbook in research and evaluation. San Diego, CA: Educational and Industrial Testing Services.

Jackson, G., McNamara, K., \& Witt, B. (2017). A framework for disaster vulnerability in a small island in the Southwest Pacific: A case study of Emae Island, Vanuatu. International Journal of Disaster Risk Science, 8(4), 358-373. https://doi.org/10.1007/s13753-017-0145-6

Jha, S., Martinez, A., Quising, P., Ardaniel, Z. \& Wang. L. (2018). Natural Disasters, Public Spending, and Creative Destruction: A Case Study of the Philippines. Tokyo: ADBI Working Paper. https://doi.org/10.2139/ssrn.3204166

Kamil, P. A., Utaya, S., \& Utomo, D. H. (2020). Improving disaster knowledge within high school students through geographic literacy. International Journal of Disaster Risk Reduction, 43, 101411. https://doi.org/10.1016/j.ijdrr.2019.101411

Khorram-Manesh, A., Lupesco, O., Friedl, T., Arnim, G., Kaptan, K., Djalali, A. R. \& Fischer, P. (2016). Education in disaster management: What do we offer and what do we need? Proposing a New Global Program. Disaster Medicine and Public Health Preparedness, 10(6), 854-873. https://doi.org/10.1017/dmp.2016.88

Labrague, L. J., Yboa, B. C., McEnroe-Petitte, D. M., Lobrino, L. R., \& Brennan, M. G. B. (2016). Disaster preparedness in Philippine nurses. Journal of Nursing Scholarship, 48(1), 98-105. https://doi.org/10.1111/jnu.12186

Leelawat, N., Mateo, C. M. R., Gaspay, S. M., Suppasri, A., \& Imamura, F. (2014). Filipinos' views on the disaster information for the 2013 Super Typhoon Haiyan in the Philippines. International Journal of Sustainable Future for Human Security, 2 (2), 6173. https://doi.org/10.24910/jsustain/2.2/1628 
Macanas, G.A., \& Rogayan, D.V., Jr. (2019). Enhancing elementary pupils' conceptual understanding on matter through Sci-vestigative Pedagogical Strategy (SPS). Participatory Educational Research, 6(2), 206-220. https://dx.doi.org/10.17275/ per.19.22.6.2

Macnight Ngwese, N., Saito, O., Sato, A., Agyeman Boafo, Y., \& Jasaw, G. (2018). Traditional and Local knowledge practices for disaster risk reduction in northern Ghana. Sustainability, 10(3), 1-17. https://doi.org/10.3390/su10030825

Malik, K., Rahman, S. M., Khondaker, A. N., Abubakar, I. R., Aina, Y. A., \& Hasan, M. A. (2019). Renewable energy utilization to promote sustainability in GCC countries: policies, drivers, and barriers. Environmental Science and Pollution Research, 26(20), 20798-20814. https://doi.org/10.1007/s1 1356-019-05337-1

Matsumoto, M., Sasaki, T., \& Muslim, D. (2018). A study on the level of disaster awareness and preparedness between Indonesian and Japanese students. Journal of Japan Society of Civil Engineers, Ser. F6 (Safety problems), 74(2), 53-62. https://doi.org/10.2208/jscejsp.74.I_53

Matunhay, L. M. (2018). Disaster preparedness and resiliency of the local government unit of Compostela. International Journal of Sciences: Basic and Applied, 42 (3), 56-67.

Mertens, D. (2005). Research and Evaluation in Education and Psychology: Integrating diversity with quantitative, qualitative, and mixed methods (2nd Ed.). Boston: Sage.

Mogato, A.G.A. (2019, April 23). Magnitude 6.1 Luzon earthquake: What we know so far. Rappler. Retrieved from https://www.rappler.com/nation/228772-updates-luzonearthquake-april-2019

Newhall, C. \& Solidum., R.U. (2017). Volcanic hazard communication at Pinatubo from 1991 to 2015. In Observing the Volcano World, pp. 189-203. Springer, Cham. https://doi.org/10.1007/11157_2016_43

Office for Disaster Risk Reduction (UN). (2019). Disaster Risk Reduction in the Philippines: Status Report 2019. Retrieved from https://www.unisdr.org/files/68265_ 682308philippinesdrmstatusreport.pdf

Office of Civil Defense - National Disaster Risk Reduction and Management Council. (2015). National progress report on the implementation of the Hyogo Framework for Action (2013-2015). Retrieved from https://www.preventionweb.net /files/43379_PHL_National HFA progress_2013-15.pdf

Ozeki, K., \& Ojima, T. (2019). Current status of disaster preparedness of pharmacies and differences in disaster awareness based on pharmacy size. Disaster Medicine and Public Health Preparedness, 13(4), 753-757. https://doi.org/10.1017/dmp.2018.160

Paton, D., Smith, L., \& Johnston, D. (2005). When good intentions turn bad: promoting natural hazard preparedness. Australian Journal of Emergency Management, 20(1), 25-30.

Paz-Alberto, A. M., Camaso, E. E., Abella, G. P. L., Genaro, C. R., \& De Guzman, C. H. E. A. (2019). GIS-assisted flood hazard assessment and mapping in selected areas in Zambales. International Archives of the Photogrammetry, Remote Sensing \& Spatial Information Sciences, XLII-4/W19, 331-337. https://doi.org/10.5194/isprs-archives-xlii4-w19-331-2019

Paz-Alberto, A. M., Ramos, G. N., Carganilla, H. M. T., Divina, C. C. C., \& Barza, J. J. J. (2016). Exposure and vulnerability assessment of buildings extracted from LIDARderived datasets in the flood plains of Santo Tomas River basin, Zambales, Philippines. International Journal of Applied Remote Sensing and GIS, 3, 1-12.

Pınar, A. (2017). What is Secondary School Students' Awareness on Disasters? A Case Study. Review of International Geographical Education Online, 7(3), 315-331. 
Quilo, Q. S., Mabini, M. A. T., Tamiroy, M. P. O., Mendoza, M. J. A., Ponce, S. L., \& Viloria, L. S. (2015). Indigenous knowledge and practices: approach to understanding disaster. Philippine Sociological Review, 63, 105-129.

Rasaki, O. E. (2019). Disaster management practices in selected university libraries in Nigeria. Journal of the Institute of Conservation, 42(2), 151-167. https://doi.org/10.1080/19455224.2019.1604395

Reid, A. (2017). Population history in a dangerous environment: How important may natural disasters have been? Masyarakat Indonesia, 39, (2), 505-525.

Republic Act No. 10121. (2010). An act strengthening the Philippine disaster risk reduction and management system, providing for the national disaster risk reduction and management framework and institutionalizing the national disaster risk reduction and management plan, appropriating funds therefor and for other purposes. Retrieved from https://www.officialgazette.gov.ph/2010/05/27/republic-act-no$10121 /$

Rogayan, D.V., Jr. (2019). I heart nature: Perspectives of university students on environmental stewardship. International Journal on Engineering, Science and Technology, 1(1), 10-16.

Rogayan, D.V., Jr., \& Nebrida, E.E.N. (2019). Environmental awareness and practices of Science students: Input for ecological management plan. International Electronic Journal of Environmental Education, 9(2), 106-119.

Saja, A. M. A., Teo, M., Goonetilleke, A., \& Ziyath, A. M. (2018). An inclusive and adaptive framework for measuring social resilience to disasters. International Journal of Disaster Risk Reduction, 28, 862-873. https://doi.org/10.1016/j.ijdrr.2018.02.004

Shahbaz, S. (2019). Disaster Preparedness and Management in Pakistan: A Systematic Review. Prehospital and Disaster Medicine, 34(Suppl. 1), s122. https://doi.org/10.1017/S1049023X19002620

Sison, B. Jr. (2013, September 24). Landslides, floods kill 22 in Zambales. The Philippine Star. Retrieved from https://www.philstar.com/headlines/2013/09/24/1237497/ landslides- floods-kill-22-zambales

Subia, E. G. S., Jocson, E. J. C., \& Florencondia, E. N. T. (2019). Flood prevention and mitigation initiatives towards a flood-free city. American Scientific Research Journal for Engineering, Technology, and Sciences, 58(1), 215-224.

Superio, D. L., Alayon, S. B., \& Oliveros, M. G. H. (2019). Disaster management practices of academic libraries in Panay Island, Philippines: Lessons from Typhoon Haiyan. Information Development, 35(1), 51-66. https://doi.org/10.1177/0266666917725905

Susanto, A., Sumarmi, \& Susilo, S. (2016). Improving natural disaster mitigation and adaptation using geographic literacy. Mediterranean Journal of Social Sciences, 7(6), 333-338. https://doi.org/10.5901/mjss.2016.v7n6p333

Taşkıran, G., \& Baykal, U. (2019). Nurses' disaster preparedness and core competencies in Turkey: a descriptive correlational design. International Nursing Review, 66(2), 165-175. https://doi.org/10.1111/inr.12501

Teo, M., Goonetilleke, A., Ahankoob, A., Deilami, K., \& Lawie, M. (2018). Disaster awareness and information seeking behaviour among residents from low socioeconomic backgrounds. International Journal of Disaster Risk Reduction, 31, 11211131. https://doi:10.1016/j.jjdrr.2018.09.008

Tiwari, K. R., \& Rayamajhi, S. (2018). Devastating monsoon: Water induced disaster management practices in Nepal. Forestry: Journal of Institute of Forestry, Nepal, 15, 57-76. https://doi.org/10.3126/forestry.v15i0.24921 
Usamah, M., Handmer, J., Mitchell, D., \& Ahmed, I. (2014). Can the vulnerable be resilient? Co-existence of vulnerability and disaster resilience: Informal settlements in the Philippines. International Journal of Disaster Risk Reduction, 10, 178-189. https://doi.org/10.1016/j.ijdrr.2014.08.007

Valenzuela, V. P. B., Esteban, M., Takagi, H., Thao, N. D., \& Onuki, M. (2020). Disaster awareness in three low risk coastal communities in Puerto Princesa City, Palawan, Philippines. International Journal of Disaster Risk Reduction, 46, 101508. https://doi.org/10.1016/j.ijdrr.2020.101508

Van Belle, G. (2008). Statistical rules of thumb (2nd Ed.). New York: John Wiley. https://doi.org/10.1002/9780470377963

Vieweg, S., Hughes, A. L., Starbird, K., \& Palen, L. (2010, April). Microblogging during two natural hazards events: what twitter may contribute to situational awareness. In Proceedings of the SIGCHI conference on human factors in computing systems (pp. 1079-1088). https://doi.org/10.1145/1753326.1753486

Wang, J.J. (2016). Study on the context of school-based disaster management. International Journal of Disaster Risk Reduction, 19, 224-234. https://doi.org/10.1016/j.ijdrr.2016.08.005

World Bank. (2005). Natural disaster risk management in the Philippines: Enhancing poverty alleviation through disaster reduction. Washington, DC: World Bank. Retrieved from https://openknowledge.worldbank.org/handle/10986/8748

World Economic Forum. (2018). The Global Risks Report 2018 (3rd Ed.). Geneva: World Economic Forum.

Zuluaga, M. C., Norini, G., Lima, A., Albanese, S., David, C. P., \& De Vivo, B. (2017). Stream sediment geochemical mapping of the Mount Pinatubo-Dizon mine area, the Philippines: Implications for mineral exploration and environmental risk. Journal of Geochemical Exploration, 175, 18-35. https://doi.org/10.1016/j.gexplo.2016.12.012

\section{Biographical Statements}

Danilo V. ROGAYAN, Jr. works at the faculty of the College of Education, Arts \& Sciences of the President Ramon Magsaysay State University - San Marcelino Campus (formerly Ramon Magsaysay Technological University) in Zambales, Philippines. He is an Associate Member of the National Research Council of the Philippines (NRCP) Division VIII (Social Sciences). His research interests include STEAM (science, technology, engineering, arts, agri/fisheries, mathematics) education, environmental science education, action research, preservice and teacher education, materials development, gender equity in education, and indigenous people.

Lea F. DOLLETE is an assistant professor of the College of Teacher Education of the President Ramon Magsaysay State University-Botolan Campus (formerly Ramon Magsaysay Technological University) in Zambales, Philippines. She finished BS Physics for Teachers at the Philippine Normal University (PNU), Manila in 2001. She is currently finishing her thesis leading to the degree MA in Education major in Physics at Bulacan State University. Her research interests include history and philosophy of science, phenomenographic study, error analysis, physics education, disaster education and instructional material development. 